\title{
Integration of mental health into primary health care ${ }^{1}$
}

${ }^{1}$ This report is extracted from the Summary report on the Expert consultation on mental health in primary health care: finalization of the guidance package for the integration of mental health into primary health care, Cairo, Egypt, 19-20 September 2017 (http:/applications.emro.who.int/docs/ IC_Meet_Rep_2017_EN_20192.pdf?ua=1, accessed 21 March 2018).

Citation: Integration of mental health into primary health care. East Mediterr Health J. 2018;24(2):221-222 https://doi.org/10.26719/2018.24.2.221

Copyright (C) World Health Organization (WHO) 2018. Some rights reserved. This work is available under the CC BY-NC-SA 3.o IGO licence (https:// creativecommons.org/licenses/by-nc-sa/3.o/igo.)

Mental, neurological, and substance use disorders are common in all regions of the world, affecting every community and age group across all income countries. While $14 \%$ of the global burden of disease is attributed to these disorders, most of the people affected - $75 \%$ in many low-income countries - do not have access to the treatment they need (1).

In response, the World Health Organization (WHO) has launched its flagship Mental Health Global Action Programme (mhGAP) to scale up care for mental, neurological and substance use disorders. The Mental Health Action Plan 2013-2020, adopted by the World Health Assembly in May 2013 (2), provides the roadmap for developing community-oriented mental health services. The Regional Framework to Scale Up Action on Mental Health in the Eastern Mediterranean Region (3) implements the provisions of the Mental Health Action Plan by identifying concrete strategic interventions through a set of intermediate indicators that can be used to monitor progress towards the targets set for 2020 (3).

One of the key strategic interventions identified in the Regional Framework is the integration of a mental health component into primary health care (3). Although this intervention has been on the agenda for over 30 years, and despite the fact that countries in the Region have pioneered the integration process, only a few countries have made tangible progress at the national level, while the majority of countries have found it difficult to transition from local, time-limited projects to scaled-up sustainable integration. Recent developments, such as the inclusion of mental health and substance use-related targets and indicators in the 2030 Agenda for Sustainable Development (4), have provided additional impetus to this effort.

The WHO Regional Office for the Eastern Mediterranean (WHO/EMRO) has taken the lead in developing a guidance package to support countries in integrating mental health interventions into their primary health care systems, based on health system building blocks and the universal health coverage approach. In addition, in view of the crisis and emergency situations prevailing in a substantial number of countries in the Region, the package includes a special section on providing integrated mental health and psychosocial support services in countries in crisis and emergency situations. This presents an opportunity to not only set up robust mental health and psychosocial support systems during the response phase, but also to build inclusive and resilient health systems.

The expert consultation, which was held at the Regional Office in Cairo, 19-20 September 2017 (5), was jointly organized by the Regional Office departments of Noncommunicable Diseases and Mental Health (NMH) and Health Systems Development (HSD), and involved both regional and international experts in public mental health and health system development. The objectives of the expert consultation were to review the draft guidance package to facilitate countries in the Region; to introduce and/or strengthen the integration of mental health interventions in primary health care; and to identify the potential entry points for the integration of mental health interventions in primary health care in both stable and humanitarian emergency settings.

\section{Summary of discussions}

1. The guidance package needs to be structured more explicitly in accordance with the 2030 Agenda for Sustainable Development in order to achieve Sustainable Development Goal 3.8: achieve universal health coverage (6). Thus, the integration of a core package of mental health interventions into primary health care is needed.

2. Governance should be given more prominence in the package, not only as an individual health system building block underpinning the process of integration, but also within each of the other sections of the package dealing with other health system building blocks. In addition, this would allow addressing the sections on advocacy and collaborative plans within the section on governance.

3. In order to help national planners and implementers, more case examples from countries of the Region and beyond are needed, which highlight the processes and mechanisms facilitating sustainable integration of mental health interventions in primary health care, as well as the challenges encountered in the process.

4. The integration of mental health services into primary health care needs to provide a strong case for investment in integration. This would offer evidence of better health outcomes and return on investment, and information on the financial and opportunity costs of failing to do so.

5. The addition of a section on health system status and emergencies would be beneficial, not only in the module on the context of the integration of mental health services in primary health care, but also in each of the 
building blocks, in order to provide an overview of the regional situation.

6. The sections of the package on human resources need to address the issues of job advertising, recruitment, staff retention, and the deployment of a health workforce that has the necessary skills to deliver holistic mental health care at all levels of care, including selfcare and self-help.

7. It is essential to specifically highlight the need to strengthen the mental health component of the pre-service training programmes of health personnel, the training programmes of family physicians, and in-service training and supervision, in the context of the core package of interventions to be delivered through primary health care.

\section{Recommendations}

1. Supporting Member States in adapting and tailoring the package to local systems to facilitate the process of integration of mental health interventions in primary health care.

2. Improving the navigability of the package and developing single-page policy briefs around individual themes targeting policy-makers, managers in the public and private sectors, nongovernmental organizations, consumers and families.

3. Review and modify the four modules of the package in light of the comments made during the consultation.

4. Organize a regional meeting during 2018 to secure the consensus of all countries of the Region, possibly with representation from other WHO regions and global partners.

5. Exploring the possibility of including the integration of mental health interventions in primary health care as an agenda item at the Sixty-fifth Session of the Regional Committee in 2018.

\section{References}

1. World Health Organization. WHO Mental Health Gap Action Programme (mhGAP). Geneva: World Health Organization; 2017 (http://www.who.int/mental_health/mhgap/en/).

2. World Health Organization. Mental Health Action Plan 2013-2020. Geneva: World Health Organization; 2013 (http://apps.who. int/iris/bitstream/10665/89966/1/9789241506021_eng.pdf?ua1).

3. WHO Regional Office for the Eastern Mediterranean Region (EMRO). Regional framework to scale up action on mental health in the Eastern Mediterranean Region. Cairo: EMRO; 2016 (http://applications.emro.who.int/dsaf/EMROPUB_2016_EN_18700. pdf?ua=1).

4. United Nations. Transforming our world: the 2030 agenda for sustainable development. New York: United Nations; 2015 (https:// sustainabledevelopment.un.org/post2015/transformingourworld).

5. WHO Regional Office for the Eastern Mediterranean. Expert consultation on mental health in primary health care: finalization of the guidance package for the integration of mental health into primary health care, Cairo, Egypt, 19-20 September 2017 (http:// applications.emro.who.int/docs/IC_Meet_Rep_2017_EN_20192.pdf?ua=1).

6. World Health Organization. SDG 3: ensure healthy lives and promote wellbeing for all at all ages. Geneva: World Health Organization; 2016 (http://www.who.int/sdg/targets/en/). 


\section{Eastern Mediterranean Health Journal reviewers' panel, 2017}

The Eastern Mediterranean Health Journal extends sincere thanks to the following experts for their generous and invaluable assistance in the review of papers considered for publications during 2017.

Arranged in alphabetical order according to the family name

\begin{tabular}{|c|c|}
\hline Ahmed Abdalla & Dawit Ayele \\
\hline Shamly Abdelfattah & Erfan Ayubi \\
\hline Alaa Ramzy Abd-Elsayed & Fereidoun Azizi \\
\hline Yetmgeta E. Abdella & Serap Argun Baris \\
\hline Abdul-Galeel Abdul-Gader & Rafic Baddoura \\
\hline Yousef Abdulrazzaq & Zahra Bahadoran \\
\hline Nada Abouelmaged & Salim Baharoon \\
\hline Basil Aboul-Enein & Ahmed Bahnassy \\
\hline Abdinasir Abubakar & Hyam Bashour \\
\hline Niveen Abu-Rmeileh & Shahrzad Bazargan-Hejazi \\
\hline Hazizi Abu Saad & Myron Belfer \\
\hline Salim Adib & Mehdi Ben-Khelil \\
\hline Mohamed Afifi & Abdulbari Bener \\
\hline Rima Afifi & Joshua Bernstein \\
\hline Sohail Agha & Douglas Bettcher \\
\hline Hassan Aguenaou & Lubna Bhatti \\
\hline Ali Ahmadi & Ahmed Bhayat \\
\hline Kabir Ahmed & Zulfiqar Bhutta \\
\hline Suhail Ahmed & Wenche Borgnakke \\
\hline Waqar Ahmed & Mohammad Boskabady \\
\hline Ahmed-Refat AhmedRefat & Tatjana Buklijas \\
\hline George Aislaitner & Evans Buliva \\
\hline Kamel Ajlouni & Pierre Carnevale \\
\hline Aysegül Aksan & Monique Chaaya \\
\hline Nadia Akseer & Venkatraman Chandra-Mouli \\
\hline Asiye Akyol & Nasrin Changizi \\
\hline Shala Al-Alaf & Irtaza Chaudhri \\
\hline Nahla Al Ali & Ismatullah Chaudhry \\
\hline Sami Al Hajjar & Sohaila Cheema \\
\hline Fatma Al Mulhim & Zahra Cheraghi \\
\hline Deena Alasfoor & Maria Chun \\
\hline Dara Al-Banna & Caroline Clarinval \\
\hline Nawal Alhamad & Emmert Clevenstine \\
\hline Ayoub Aljawaldeh & Alison Commar \\
\hline Khalid AlJohani & Elena Cruz-Ferro \\
\hline Yagoub Al-Kandari & Antonella Daniele \\
\hline Hamid Allahverdipour & Mike Daube \\
\hline Kate Allen & Bothaina Deghedi \\
\hline Tawfiq Almadi & Anna Dencker \\
\hline Kamelia Amazian & Hani Dimassi \\
\hline Jamal Al-Menayes & Henry Doctor \\
\hline Ahmad Al-Nawafleh & Laila Dorgham \\
\hline Eman Alnazly & Leila Doshmangir \\
\hline Jamela Al-Raiby & Heidi Doughty \\
\hline Omnia Al-Rashidy & Trevor Duke \\
\hline Khaldoun Al-Roomi & Khalil El Asmar \\
\hline Dr. Arshad Altaf & Mohamed El-Barrawy \\
\hline Peyman Altan & Faysal El Kak \\
\hline Eman Aly & Nada El Osta \\
\hline Ahmed Al-Yousfi & Lana El Osta \\
\hline Shaikh Khurshid Anwar & Manar El Sheikh \\
\hline Morsi Arab & Wafaa Eldin \\
\hline Nada A-Rahman & Engy El-Ghitany \\
\hline Thalia Arawi & Abdel-Hady El-Gilany \\
\hline Ali Ardalan & Taghareed Elhoseeny \\
\hline Soheila Asgari & Dalal Elkaffash \\
\hline Fazal Ather & Mohamed El-Kalioby \\
\hline Osama Awad & Safaa El-Kogali \\
\hline
\end{tabular}

Nermine El-Maraghy

Dawlat El-Miligy

Abdel Rahman El-Naggar

Maha El-Rabbat

Mervat El-Rafie

Farouk El-Sabban

Ihab El-Sawy

Maged El-Setouhy

Fawzi El-Shobaki

Fatma El-Zanaty

Kaia Engesveen

Mohammad Eslami

Ghada El-Hajj Fuleihan

Morteza Fallahpour

Mohammad Fararouei

Jawad Fares

Hani Farouk

Nada Farsi

Mahmoud Fathalla

Michael Favin

Ali Feizzadeh

John Fisher

Monica Flores

Alfredo Fort

Akbar Fotouhi

Heba Fouad

Mohsen Gadallah

Salma Galal

Margaret Gerbasi

Saeideh Ghaffarifar

El-Kebir Ghandour

Marina Gharibian

cheherezade Ghazi

Maryam Ghobadzadeh

Karima Gholbzouri

Kamal Gholipour

Mohammad Ghorbani

Sara Gilani

Mahdieh Golzarand

Cornelius Goos

Mohammad Gouya

Jagadish Guria

Wafa Habbal

Sevil Hakimi

RJ Halbert

Samia Halileh

Hossam Hamdy

Saima Hamid

Ali Hasab

Mohsen Hassan

Sondus Hassounah

Joumana Hermez

Gholamreza Heydari

Tamer Hifnawy

Keith Humphreys

Abdullatif Husseini

Mohammed Ibrahim

Seema Irfan 
Rasdi Irniza

Ebrahim Jaafaripooyan

Samer Jabbour

Bismeen Jadoon

Nader Jahanmehr

Sahar Jamal

Marzieh Javadi

Hassan Joulaei

Ibrahim Kabbash

Rita Kabra

Nassim Kamar

Laila Kamel

Mohamed Kamel

Maria Kantzanou

Rita Karam

Akram Karimi

Farzaneh Kashefi

Zeinab Khadr

Fatima Khalifeh

Haris Khan

Nazeer Khan

Soghra Khani

Ibrahim Kharboush

Rana Khatib

Mehrnaz Kheirandish

Ardeshir Khosravi

Michele Kosremelli Asmar

Wesam Kurdi

Faris Lami

Bagher Larijani

Yong-Jae Lee

Mondher Letaief

Francesco Locatelli

Veema Lodhia

Anna-Leena Lohiniva

Tamara Lotfi

Graham MacGregor

Ramez Mahaini

Osama Maher

Soad Mahfoozpour

Esra Mahgoub

Sawsan Majali

Nisrine Makarem

Mamunur Malik

Salah Mandil

Adel Mansour

Azhar Maqbool

Seyed Marandi

Mohamed Massoud

Rashad Massoud

Benoit Mathivet

Lazarous Mbulo

Bryan McIntosh

Marie Merheb

Anthony Miller

Salma Moawed

Farhat Moazam

Ali Moazzam

Iqbal Mochtar

Azza Mohamed

Mohamed Izham Mohamed Ibrahim

Fahzad Mohammadi

Niloofar Mohammadzadeh

Mohammadreza Mohebbi

Ali Mokdad

Talat Mokhtariazad
Azrakesh Mokri

Hoomen Momen

Mahmood Moosazadeh

Steve Morse

Iliana Mourad

Haider Mousa

Suaad Moussa

Afarin Rahimi Movaghar

Abdulkader Murad

Abu Mustafa

Ashraf Nabhan

Amr Nadim

Hanan Najmi

May Nassar

Saharnaz Nedjat

Mahmood Nekoei-Moqhadam

Brett Nelson

Kamran Niaz

Alireza Noroozi

Samia Nosseir

Nuha Nuwayri-Salti

Omar Obeid

Majdouline Obtel

Michael Odenwald

Tarek Okasha

Nasrin Omidvar

Abdalla Osman

Afshin Ostovar

Tarek Owaidah

Mehdi Pasalar

Margaret Peden

Harold Perl

Brennan Peterson

Michal Pirozynski

Giorgi Pkhakadze

Vinayak Prasad

Pekka Puska

Maqbool Qadir

Mir Faeq Ali Quadri

Huma Qureshi

Mostafa Amini Rarani

Ghada Radwan

Mervat Rady

Ahmed Ragab

Abbas Rahimiforoushani

khaled Rahmani

Daniel Rainkie

Vahid Rakhshan

Parveen Rasheed

Maryam Rassouli

Hamayun Rathor

Hamid Ravaghi

Richard Rawson

Nesrine Rizk

John Rovers

Bassem Saab

Ali Sadek

Shahram Saedi

Khalid Saeed

Najibullah Safi

Leyla Saglam

Hala Sakr

Mohammad Saleh

Eman Salem

Muhammad Arif Nadeem Saqib

Raja Sawaya
Shekhar Saxena

Stephen Schmaltz

Jane Scott

Salaam Semaan

Nazar Shabila

Hafed Shadid

Abdolreza Shaghaghi

Amira Shaheen

Rizwana Shaikh

Elham Shakibazadeh

Ali Shamseddine

Sherine Shawky

Mohammad Shirzadi

Abla Sibai

Cees Smit Sibinga

Catherine Smith

Hanan Soliman

Hamid Soori

Eva Steliarova-Foucher

Fatima Suleman

Carolyn Sun

Mashid Taj

Menderes Tarcan

Kholoud Tayel

Sally Temraz

Gill Ten Hoor

Jean-Francois Tessier

Imad Toufeili

Nhu Tran Minh

Zaeem ul Haq

Jinan Usta

Hassan Vatandoost

Raman Velayudhan

Alain Vergnenegre

Bipin Verma

Iman Wahdan

Marcia Ward

Ruth Wells

Kyle Wilby

Tewes Wischmann

Mahamet-Saleh Yahya

Suayib Yalcin

Bahareh Yazdizadeh

Jesse Young

Atefe Zabihi Zazoly

Nevio Zagarian

Nida Zahid

Golara Zahmatkesh

Gaffar Zaman

Kazem Zendehdel

Tayebe Ziaei

Fabio Zicker

Joseph Ziegler 
1. Papers submitted for publication to the Eastern Mediterranean Health Journal (EMHJ) must not have been published, accepted for publication or currently be under consideration for publication elsewhere. The World Health Organization (WHO) Regional Office for the Eastern Mediterranean reserves all rights of reproduction and republication of material that appears in the EMHJ.

2. Papers submitted for publication to the EMHJ should conform with the Recommendations for the Conduct, Reporting, Editing and Publication of Scholarly Work in Medical Journals (http://www.icmje.org/icmjerecommendations.pdf) of the International Committee of Medical Journal Editors (ICMJE).

3. Ethical considerations: Where applicable, a statement must be included indicating approval for the study was granted by the ethics committee/institutional review board of the relevant institution. Authors should verify where appropriate that all persons on whom research has been carried out have given their voluntary, informed, written consent, and where participants (living or dead) were unable to give such consent, that surrogate consent was obtained. Authors may be asked to supply such consent forms.

Conflicts of interest: Authors will be asked to provide details of any competing interests and funding. Please see the ICMJE Recommendations.

4. Reporting guidelines: EMHJ encourages and recommends authors to adhere to the best research protocols available and follow established reporting guidelines. Reporting guidelines are available at the EQUATOR Network (http://www.equator-network.org/). The key guidelines for research in the field of public health are: CONSORT (guidelines for reporting randomized trials); STROBE (guidelines for reporting observational studies); PRISMA (Preferred Reporting Items for Systematic Reviews and Meta-Analyses); STARD (Standards for Reporting of Diagnostic Accuracy); COREQ (Consolidated criteria for reporting qualitative research); CARE (guideline for clinical case report) as well as the COCHRANE handbook (for systematic reviews of interventions). Links to these sites and other useful resources are available under "Useful resources for authors and reviewers" (http:// www.emro.who.int/emh-journal/links/).

5. Following WHO and ICMJE recommendations, EMHJ requires registration of clinical trials in a public trials registry as a condition of consideration for publication. Authors are recommended to register in one of the clinical trials registries certified by WHO and ICMJE which are available at the International Clinical Trials Registry Platform (http://www.who.int/ictrp/en/).

6. Submission: Original papers written in Arabic, English or French may be submitted for consideration through our online submission system. Instructions on submitting a manuscript through the online system and access to the system can be found on our website at: http://www.emro. who.int/emh-journal/authors/ and by clicking on Editorial Manager.

7. Abstracts of papers accepted for publication will be translated into all three languages. To ensure the correct spelling of authors' names to accompany the Arabic abstract, authors writing in English or French but whose mother tongue is written using Arabic characters should provide their full names in Arabic script along with transliterations in English or French.
8. Manuscripts should be prepared in word processed format (preferably Microsoft Word) double-spaced, single column, preferably using Times New Roman script, font size 12.

9. All papers considered for publication will be peer reviewed. The Editorial Board reserves the right to accept or reject any paper based on the reviewers' comments, scientific rigor and suitability for the journal. Papers are accepted on the understanding that they are subject to statistical and editorial revision as deemed necessary, including abridgement of the text and omission of tabular or graphic material.

10. Topics: The subject of the paper should pertain to public health or a related biomedical or technical subject within the field of interest of the WHO, and should have particular relevance to the Eastern Mediterranean Region.

11. The title of the paper should be as concise as possible, preferably not more than 15 words. All authors should have made material contribution to the design, analysis or writing of the study and have approved the final version submitted. No change in authorship will be permitted after the paper has been accepted for publication and any change before this must be agreed by all authors listed. Authors may be asked to verify their contribution. Names of other contributors may be included in the acknowledgements. Please see the ICMJE Recommendations for authorship and contributorship.

12. Structured abstracts: Submissions should include a structured abstract in this format: Background; Aims; Methods; Results; and Conclusion. The structure can be flexible if a paper warrants it and a justification offered by the author at submission.

13. Research articles: Papers reporting original research findings should follow this format: Background, Objectives; Methods; Results; Discussion and Conclusion. The text of Research articles and Reports should not exceed 3000 words (excluding references). A structured abstract should not exceed 250 words (see note 12). The maximum number of references permitted is 35 and must include DOIs if available. The number of tables and figures should not exceed 5 .

14. Review articles: (i.e. critical assessments of research on topics of relevance to public health in the Region). These should contain sections dealing with objectives, sources, methods of selection, compilation and interpretation of data and conclusions. The text should not exceed 3000 words (excluding the accompanying abstract, references, tables and figures), and should be accompanied by an abstract of not more than 250 words (see note 12). The number of tables and figures should not exceed 5 .

15. Reports: (i.e. papers reporting on projects of public health relevance to the Eastern Mediterranean Region). Manuscript specifications (length, references, tables/ figures) are the same as a research article, but abstract length should not exceed 150 words.

16. Short communications: Articles which do not constitute a complete research study but are of particular relevance or importance to public health issues in the Region may be considered for publication. The text should not exceed 1500 words (excluding references), and should be accompanied by a structured abstract (see note 12) of not more than 150 words. The number of tables and figures should not exceed 3 .

17. Case reports: Only reports of cases of an unusual nature are considered for publication. Text should include an 
Introduction, the Report of the case(s) and a Discussion. The text should not exceed 1500 words and the number of references kept to a minimum. The abstract should not exceed 150 words.

18. Letters to the Editor: Letters commenting on published articles are welcome. Letters will be sent to the authors of the original article for their comments, and these will be published along with the letter. The text of letters should not exceed 500 words.

19. References: In-text citations of published works should be limited to essential up-to-date references. These should be numbered separately as they occur in the text with sequential Arabic numerals in parentheses, e.g. $(1,5-8)$. These references should appear in a numbered list on a separate page after the Discussion. They should contain the following elements as appropriate: name(s) and initial(s) of author(s); title of paper or book in its original language plus translation; for research articles, abbreviated name of journal plus volume number and page range; for books and other texts, place of publication (city and country) and name of publisher (commercial or institutional); and date of publication and DOI number; for texts published exclusively on the Internet, exact URL of the page cited and date when last accessed.

For texts with up to 6 authors, all authors must be named. For texts with more than 6 authors, the first 6 authors should be named followed by "et al".

The following are examples of the Journal's preferred style: Book:

Al Hamza B, Smith A. The fifth sign of identity. Cairo: American University Press; 1990.

Journal article:

Rehmani R, Elzubair AG, Al Maani M, Chaudary IY, Al

Qarni A, Khasshogi T et al. Population-based health survey in eastern region of Saudi Arabia. East Mediterr Health J. 2013; 19(5):417-25

Document:

Al-Itneen M, ed. The principles of uncertainty. Geneva:

World Health Organization; 1985 (WHO/DOC/537).

Thesis

Smith S. Use of healthcare services by the elderly with the introduction of technical innovations. London: Drake University; 2013.

Web text:

Child growth standards. Geneva: World Health

Organization; 2006 (http://www.who.int/childgrowth/en/, accessed 8 October 2008).

20. Figures and tables with appropriate captions should each be on a separate page and numbered sequentially with Arabic numerals. Each figure and table must be referred to in the text. Where appropriate, sources should be given. If any figures, tables or other materials have been copied from other sources, authors have the sole responsibility for securing the necessary permission. In order to avoid layout problems in final production, tables and figures should be limited as far as possible.

Figures must be supplied in a format which can be edited, preferably Microsoft Excel format, and figures derived from data must be accompanied by those data, e.g. Excel data sheet, to enable redrawing if necessary. Photographs and illustrations should also be sent as separate files. The preferred format is JPG or TIFF; resolution should be minimum 300 dpi.

21. Submissions that do not comply with these guidelines will be returned to the authors for correction before being considered for publication. 


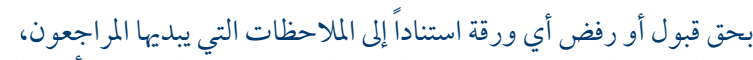

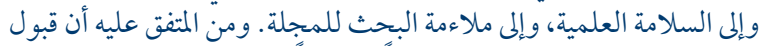

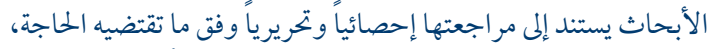

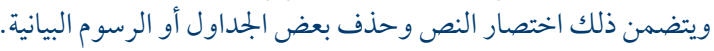

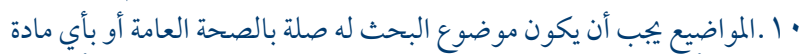

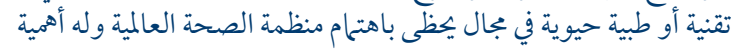
خاصة لإقليم شرق المتوسط.

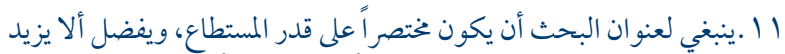

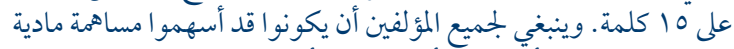

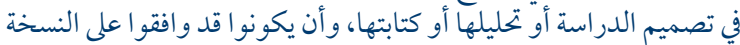

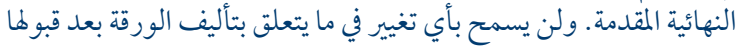

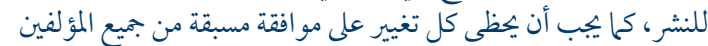

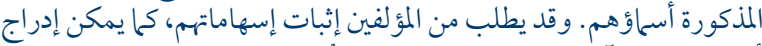

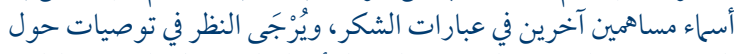

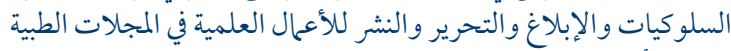

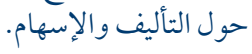

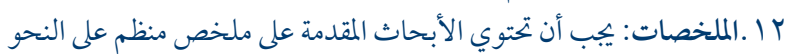

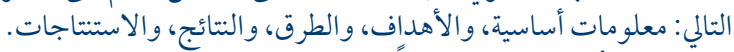

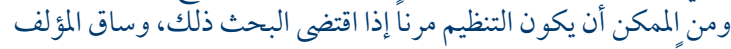

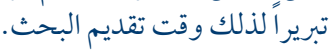

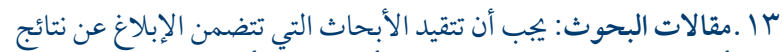

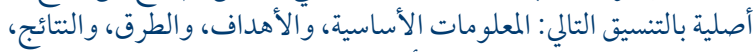

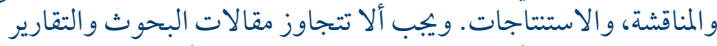

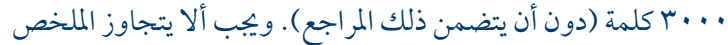

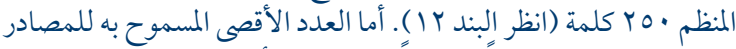

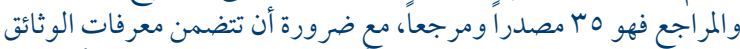

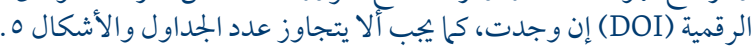

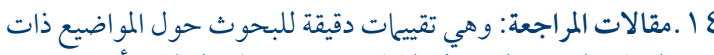

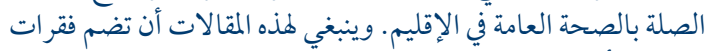

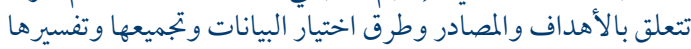

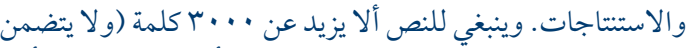

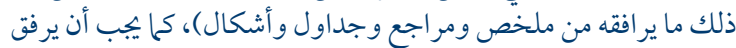

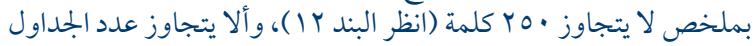
و الأشكال ه.

10 .التقارير: وهي تقارير أعدت حول مشاريع ذات صلة بالصات الصحة العامة في إقليم

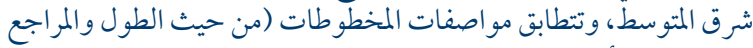

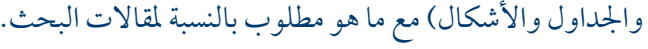

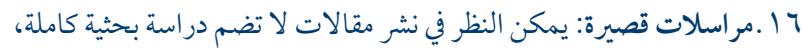

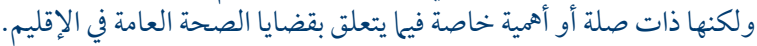

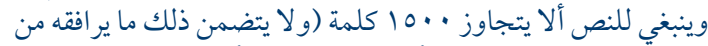

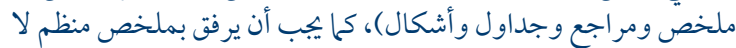

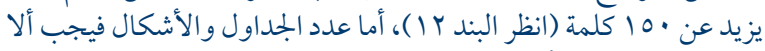

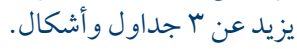

IV

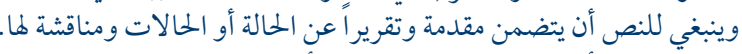

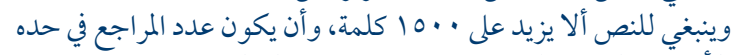

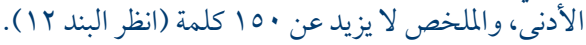

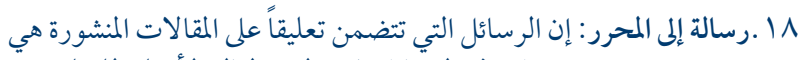

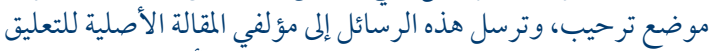

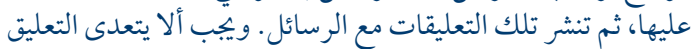

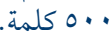

19 ـالمراجع: يجب أن يقتصر الاقتباس من الأعمال المنشورة على المراجع الأساسية

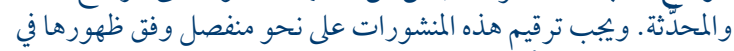

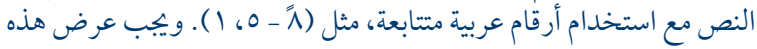

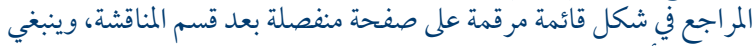

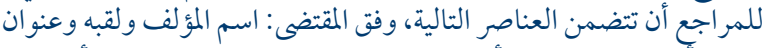

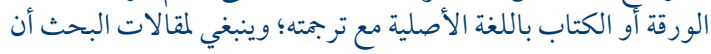

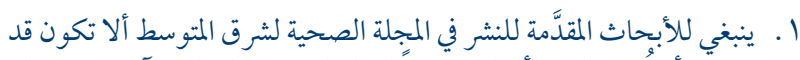

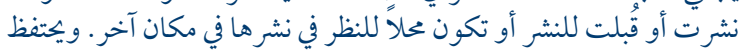

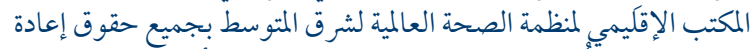

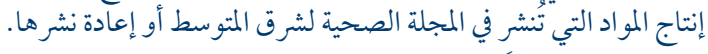

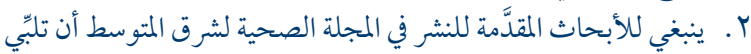

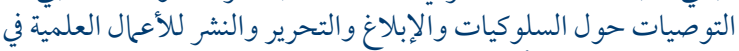

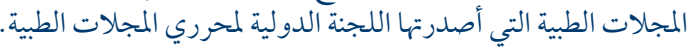

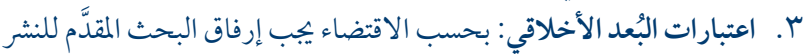

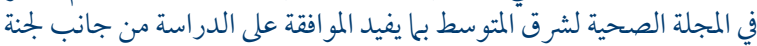

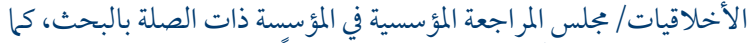

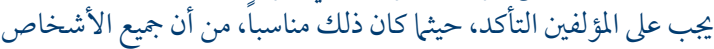

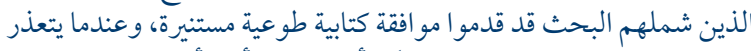

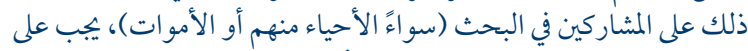

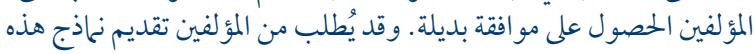

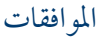

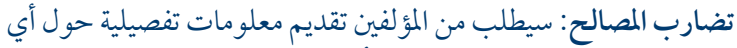

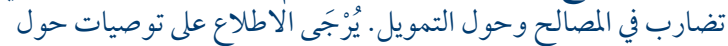

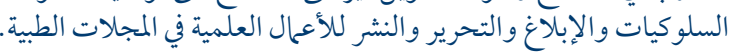

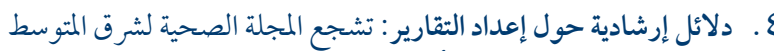

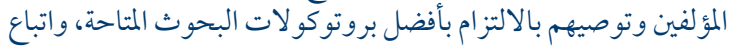

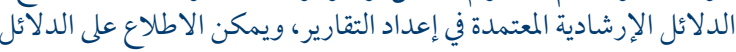

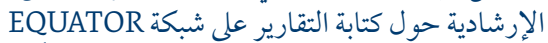
(http://www.equator-network.org)

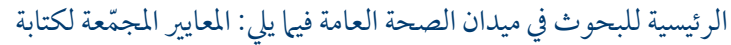

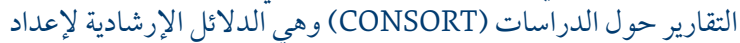

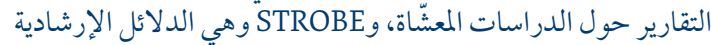

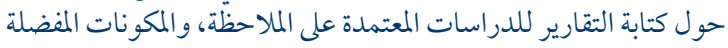

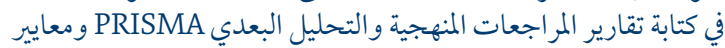

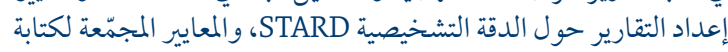

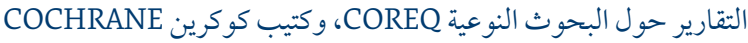

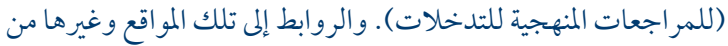

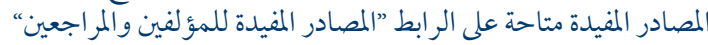
.(http://www.emro.who.int/emh-journal/links)

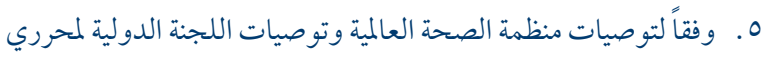

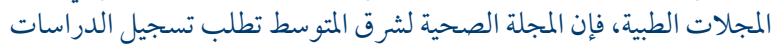

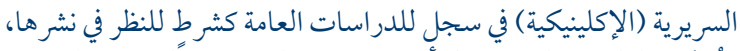

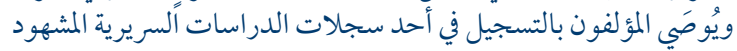

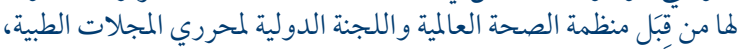

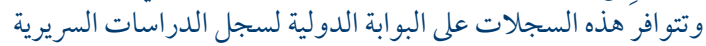
(http://www.who.int/ictrp/en)

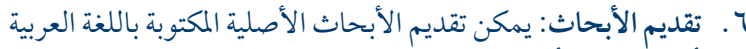

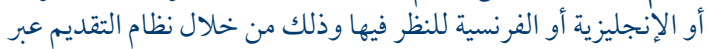

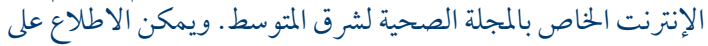

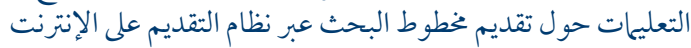

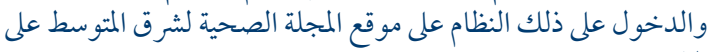
الإنترنت، وهو عل وال

ثم (http://www.emro.who.int/emh/emh-journal/authors) الضغط على أيقونة Editorial Manager.

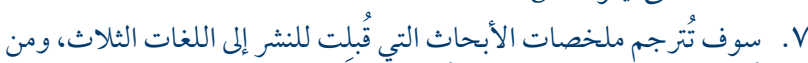

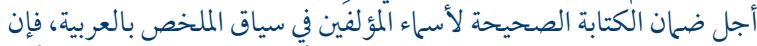

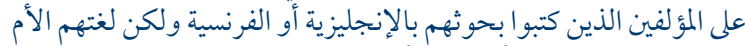

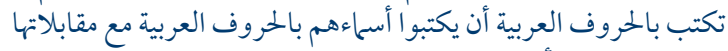
باللغة الإنجليزية أو بالفرنسية.

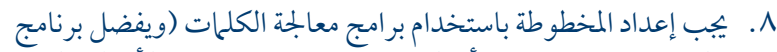

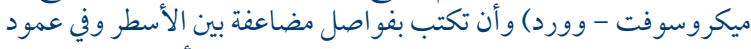

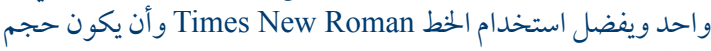
الخط r 1 ا

9 ه. تخضع جميع الأبحاث التي تقدم للنشر لمراجعة الزملاء، وتحتفظ هيئة التحرير 


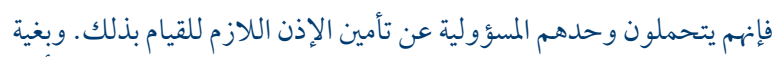

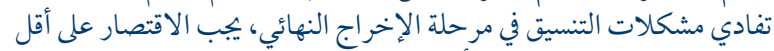

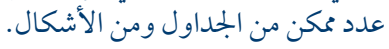

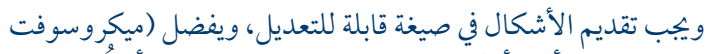

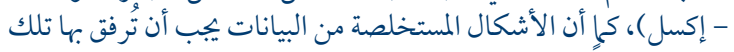

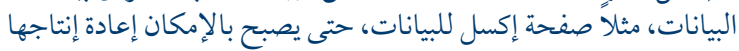

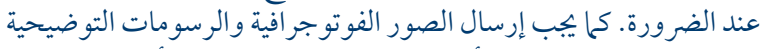

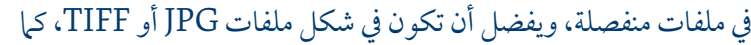

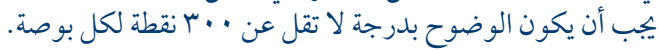

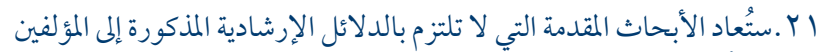
من أجل تصحيحها قبل النظّر في نشرها.
تتضمن الاسم المختصر للمجلة مع رقم المجلد وحدو المد الصفحات. وينبنغي

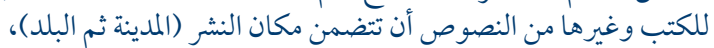

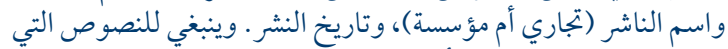

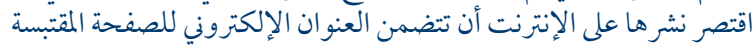

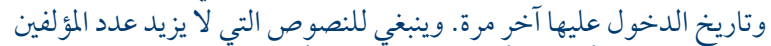

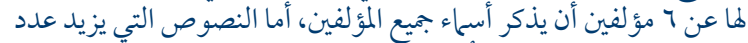

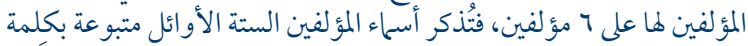

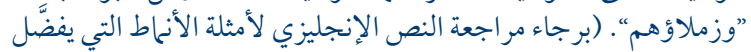

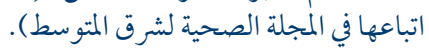

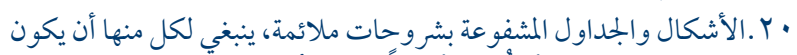

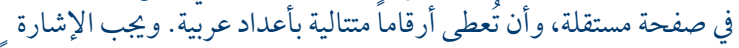

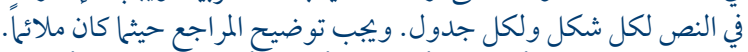
وإذا ما نسخ المؤلفون أي شكل أو جدول ولي أو مادة أخرى من مراجع المر أخرى، 
1. Les articles soumis pour publication à La Revue de Santé de la Méditerranée orientale ne doivent pas avoir été publiés, avoir été acceptés pour publication dans d'autres revues ou être en cours d'examen par d'autres revues. Le Bureau régional de l'Organisation mondiale de la Santé (OMS) pour la Méditerranée orientale se réserve tous les droits de reproduction et de republication des matériels qui paraissent dans La Revue de Santé de la Méditerranée orientale.

2. Les articles soumis pour publication à La Revue de Santé de la Méditerranée orientale doivent être conformes aux Recommandations pour la conduite, la présentation, la rédaction et la publication des travaux de recherche soumis à des revues médicales (http://www. icmje.org/recommendations/translations/french2015. pdf) de l'International Committee of Medical Journal Editors (Comité international des éditeurs de revues médicales, ICMJE).

3. Considérations éthiques : Le cas échéant, une déclaration devra être incluse, indiquant que le Comité d'éthique ou le Comité d'examen institutionnel de l'organisme concerné a donné son accord à l'étude. Les auteurs doivent vérifier, le cas échéant, que toutes les personnes sur lesquelles la recherche porte ont donné leur consentement volontaire et informé par écrit et que si certains participants (en vie ou décédés) n'ont pas pu le donner, un consentement de substitution a été obtenu. Il peut être demandé aux auteurs de fournir ce type de formulaire de consentement.

Conflits d'intérêts : Il sera demandé aux auteurs de préciser tout conflit d'intérêts et financement. Veuillez vous reporter aux recommandations de l'ICMJE.

4. Directives de présentation : La Revue de Santé de la Méditerranée orientale encourage les auteurs à respecter les meilleurs protocoles de recherche disponibles et leur recommande de suivre les directives de présentation établies. Les directives de présentation sont disponibles sur le site Web du réseau EQUATOR (http://www. equator-network.org/). Les principales directives pour la recherche en santé publique sont les suivantes : directives CONSORT (essais randomisés) ; directives STROBE (études observationnelles); directives PRISMA (revues systématiques et méta-analyses) ; directives STARD (normes de présentation de rapports concernant l'exactitude de diagnostic); critères COREQ (recherche qualitative); directives CARE (publication de cas cliniques) et le manuel COCHRANE (pour les revues systématiques des interventions). Les liens vers ces sites Web et d'autres ressources utiles sont disponibles sous la rubrique « Ressources à l'intention des auteurs et des réviseurs 》 à l'adresse suivante : http://www.emro.who.int/fr/emhjournal/links/.

5. Suite aux recommandations de l'OMS et de l'ICMJE, La Revue de Santé de la Méditerranée orientale impose comme condition de publication que les essais cliniques soient enregistrés auprès du registre public des essais cliniques. Il est recommandé aux auteurs d'enregistrer leurs essais dans un des registres des essais cliniques certifiés par l'OMS et l'ICMJE disponibles dans la base de données du Système d'enregistrement international des essais cliniques (http://www.who.int/ictrp/fr/).

6. Soumission : Les articles originaux rédigés en anglais, arabe ou en français peuvent être soumis pour examen en utilisant notre système en ligne. Les instructions relatives à la soumission d'un manuscrit en utilisant le système en ligne sont disponibles en anglais sur notre site Web accessibles à l'adresse suivante :

http://www.emro.who.int/emh-journal/authors/, et en cliquant sur « Editorial Manager ».

7. Les résumés des articles acceptés pour publication seront traduits dans les trois langues. Pour assurer que les noms des auteurs soient correctement écrits dans les résumés en arabe, les auteurs rédigeant en anglais ou en français mais dont la langue maternelle s'écrit en caractères arabes doivent fournir leur nom complet en écriture arabe avec une translittération de leur nom en anglais ou en français.

8. Les manuscrits doivent être préparés en format traitement de texte (Microsoft Word, de préférence), avec double interlignage, mise en page d'une seule colonne, police Times New Roman, taille de caractère 12 .

9. Tous les articles dont la publication est envisagée seront revus par des pairs. Le Comité de rédaction se réserve le droit d'accepter ou de refuser tout article, sur la base des commentaires des réviseurs, de la rigueur scientifique et de la pertinence de l'article pour La Revue. Les articles sont acceptés sous réserve de la révision statistique et rédactionnelle dont ils feront l'objet, comme jugé nécessaire, ce qui peut amener à abréger le texte et à supprimer certaines données présentées sous forme de tableaux ou de graphiques.

10. Sujets : Le sujet de l'article doit concerner la santé publique ou un autre sujet biomédical ou technique connexe faisant partie du champ d'intérêt de l'OMS, et se rapporter plus particulièrement à la Région de la Méditerranée orientale ou revêtir une importance particulière pour celle-ci.

11. Le titre de l'article doit être aussi concis que possible, et de préférence ne pas dépasser 15 mots. Tous les auteurs devraient avoir apporté une contribution importante à la conception, à l'analyse ou à la rédaction de l'étude et avoir approuvé la version finale soumise. Aucun changement dans les noms des auteurs ne sera autorisé après l'acceptation de l'article pour publication; avant cette acceptation, tout changement doit être accepté par l'ensemble des auteurs figurant dans la liste. Une vérification de leur contribution peut être demandée aux auteurs. Les noms d'autres contributeurs peuvent être inclus dans les remerciements. À ce sujet, veuillez vous reporter aux ICMJE recommendations for authorship and contributorship [Recommandations de l'ICMJE relatives à la qualité d'auteur et de contributeur].

12. Résumés structurés : Les articles soumis devraient inclure un résumé structuré organisé selon les titres suivants : Contexte ; Objectifs ; Méthodes ; Résultats et Conclusion. La structure peut être ajustée selon les besoins de l'article et si l'auteur fournit une justification au moment de la soumission.

13. Articles de recherche : Les articles présentant des résultats de recherche originale devront suivre le format suivant : Contexte; Objectifs ; Méthodes ; Résultats et Conclusion. Le texte des articles et des rapports de recherche ne doit pas excéder 3000 mots (références exclues). Un résumé structuré ne doit pas dépasser 250 mots (voir paragraphe 12). Le nombre maximal de références autorisées est de 35 et les identifiants d'objet numérique (DOI) doivent être inclus le cas échéant. Le texte ne doit pas comporter plus de cinq tableaux ou figures. 
14. Articles d'analyse : il s'agit d'évaluations critiques d'études de recherche sur des sujets pertinents concernant la santé publique dans la Région. Ils doivent être composés de paragraphes traitant des objectifs, des sources, des méthodes de sélection, de la compilation et de l'interprétation des données et des conclusions. Le texte ne doit pas excéder 3000 mots (résumé, références, tableaux et figures exclus) et doit être accompagné d'un résumé de 250 mots au maximum (voir paragraphe 12). Le nombre maximal de tableaux et de figures autorisé est de 5 .

15. Rapports : il s'agit d'articles présentant des projets pertinents de santé publique dans la Région de la Méditerranée orientale. Le format des manuscrits (longueur, références, tableaux et figures) est le même que pour les articles de recherche mais la longueur des résumés ne doit pas excéder 150 mots.

16. Communications brèves : Les articles ne constituant pas une étude de recherche complète, mais présentant un intérêt ou revêtant une importance particulière pour les questions de santé publique dans la Région peuvent être examinés pour publication. Le texte ne doit pas excéder 1500 mots (références exclues) et doit être accompagné d'un résumé de 150 mots au maximum. Le nombre maximal de tableaux et de figures est de 3 .

17. Études de cas : Seules les études de cas inhabituels seront examinées pour publication. Le texte doit comprendre une introduction, un exposé du/des cas et une discussion. Il ne doit pas excéder 1500 mots et le nombre de références doit être minimal. Il n'est pas nécessaire de fournir un résumé.

18. Lettres à la rédaction : Les lettres commentant des articles publiés sont les bienvenues. Elles seront envoyées aux auteurs de l'article afin qu'ils fournissent leurs commentaires, qui seront publiés aux côtés de la lettre. Le texte des lettres ne doit pas dépasser 500 mots.

19. Références : Les citations dans le texte de travaux publiés doivent être limitées aux références essentielles récentes. Elles doivent être numérotées séparément à l'aide de chiffres arabes indiqués entre crochets, par exemple (1,5-8). Les références doivent figurer sous forme de liste numérotée sur une page séparée après la partie « Discussion ». Elles doivent contenir les éléments suivants, selon le cas : nom(s) et initiales du ou des auteurs ; titre de l'article ou de l'ouvrage dans sa langue originale ainsi que sa traduction; pour les articles de recherche, le nom abrégé de la revue ainsi que le numéro du volume et les pages concernées ; pour les ouvrages et autres textes, le lieu de publication (ville et pays) et le nom de la maison d'édition (commerciale ou institutionnelle) ; la date de publication et l'identifiant d'objet numérique (DOI) ; pour les textes publiées exclusivement sur Internet, l'URL exact de la page citée et la date du dernier accès.

Lorsque les textes comptent moins de six auteurs, tous les auteurs doivent être nommés. Lorsque les textes comptent plus de six auteurs, seul les noms des six premiers auteurs sont mentionnés, suivis de « et al. ».

Exemples du style préféré de La Revue :

Livre :

Al Hamza B, Smith A. The fifth sign of identity. Cairo, American University Press, 1990.

Article de revue :

Rehmani R, Elzubair AG, Al Maani M, Chaudary IY, Al Qarni A, Khasshogi T et al. Population-based health survey in eastern region of Saudi Arabia. East Mediterr Health J. 2013; 19(5):417-25.

Document :

Al-Itneen M, ed. The principles of uncertainty. Geneva, World Health Organization, 1985 (WHO/DOC/537). Thèse :

Smith S. Use of healthcare services by the elderly with the introduction of technical innovations. London: Drake University; 2013.

Texte Web :

Child growth standards. Geneva, World Health

Organization, 2006 (http: //www. who. int/childgrowth/en/, consulté le 8 octobre 2008).

20. Les figures et les tableaux accompagnés des légendes appropriées doivent être placés chacun sur une feuille séparée, numérotés en chiffres arabes selon leur ordre. Chaque figure et chaque tableau doivent être référencés dans le texte, et le cas échéant, les sources doivent être indiquées. Si des figures, tableaux ou d'autres matériels ont été copiés d'autres sources, les auteurs portent l'entière responsabilité d'obtenir les autorisations nécessaires. Afin d'éviter les problèmes de mise en page lors de la production finale, le nombre de tableaux et de figures doit être aussi limité que possible.

Les figures doivent être fournies dans un format permettant les modifications, de préférence Microsoft Excel, et celles qui sont établies à partir de données doivent être accompagnées de ces données, sur une fiche technique Excel par exemple, pour permettre une recomposition, le cas échéant. Les photographies et illustrations doivent être envoyées dans des fichiers séparés. Les formats préférés sont JPG et TIFF, et la résolution des images doit être de 300 dpi au minimum.

21. Les manuscrits ne respectant pas ces directives seront renvoyés à leurs auteurs pour correction avant d'être examinés en vue de la publication. 